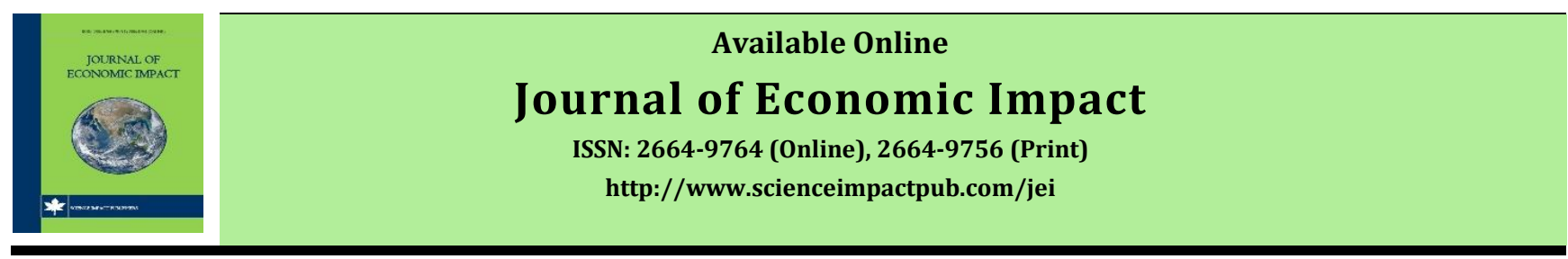

\title{
CRITICAL ANALYSIS OF RURAL DEVELOPMENT INITIATIVES IN PAKISTAN
}

\section{Muhammad Luqman a,*, Muhammad Umer Mehmood a, Muhammad Farooq b, Tariq Mehmood c Muhammad Waqar d, Muhammad Yaseen a, Mukkram Ali Tahir e}

\author{
${ }^{a}$ Department of Agricultural Extension, College of Agriculture, University of Sargodha, Sargodha, Pakistan \\ ${ }^{b}$ Department of Education, University of Sargodha, Sargodha, Pakistan \\ ${ }^{c}$ Department of Forestry, College of Agriculture, University of Sargodha, Sargodha, Pakistan \\ ${ }^{d}$ Department of Agricultural Engineering, KFUEIT, Rahim Yar Khan, Pakistan \\ e Department of Soil \& Environmental Sciences, College of Agriculture, University of Sargodha, Pakistan
}

\section{ARTICLE INFO}

\section{Article history}

Received: May 12, 2021

Revised: August 21, 2021

Accepted: August 23, 2021

\section{Keywords}

Rural poverty

Rural development initiatives

Rural support programmes

NGOs

\section{ABSTRACT}

Rural development agencies have been regarded as important performers in terms of influencing development policies and programmes in rural areas of the world. The main focus of these programmes is to uplift the living standard of the masses in rural areas through sustained growth in the rural economy. To improve the livelihoods of rural communities, the government has adopted various rural development programmes, but the majority of them left very little effect on the ground. Many of these programmes had been inspired by the western paradigm. Categorically the efforts to uplift the livelihood of the rural population in the North-Western Pakistan, have gained little success. According to recent reports, about one-third population of the mountainous region is still facing the problem of food insecurity, poverty and hunger which results in economic and political instability. Considering this, the government has launched many rural development programmes but almost all of them were terminated after gaining little success. Although the overall approach was institutional in nature but it failed to promote institutional aspect of rural development. Leading constraints to the rural developmental strategies include shortage of funds, dominated status of bureaucracy and lack of coordination among the implementing agency and local community. Besides state owned programmes for rural development, many non-government organizations (NGOs) are also involved in the theme of development that is participatory for decades. Among those initiatives, Agha Khan Rural Support Programme (AKRSP) remained quite successful in northern areas of Pakistan. However, rural development through a participatory approach is still far behind the predicted results, and these organizations are facing problems in delivering welfare services to the rural poor as they are being blamed that they are working on the western agenda.

\footnotetext{
*Email: muhammad.luqman@uos.edu.pk

https://doi.org/10.52223/jei30221038

(C) The Author(s) 2021.

This is an open access article under the CC BY license (http://creativecommons.org/licenses/by/4.0/).
}

\section{INTRODUCTION}

Rural development is a multi-dimensional phenomenon and multidisciplinary area of policy and research. It is one of the major concerns of majority of the development organizations and practitioners around the globe (Saqib et al., 2019). The idea of rural development emerged in 1960s and 1970s. It achieved maximum momentum with increasing realization that although industrial and economic growth is important for the economic growth of any country (Ellis and Biggs, 2001). But, the development of rural areas is also essential for any national sustainable developmental growth (Munawar et al., 2021). The primary reason behind the concerns of development organizations regarding sustainable development in rural areas is high rate of poverty in these areas, especially in the developing regions, including Pakistan (UNDP, 2020). In such countries, agricultural production is dominated by small landholders who are considered as most deprived and neglected masses of the society (Gautam and 
Andersen, 2016). Prospects of economic growth in such countries are very low (World Bank, 2018). Research studies proved a close interlink and relationship between rural and agricultural development with special focus in developing regions where the county's national economy largely depends upon agricultural activities (Luqman et al., 2021; Singh, 2007; Welteji, 2018). Rural development through agricultural activities plays a critical role in developing rural economies on sustained basis (Ward et al., 2005).

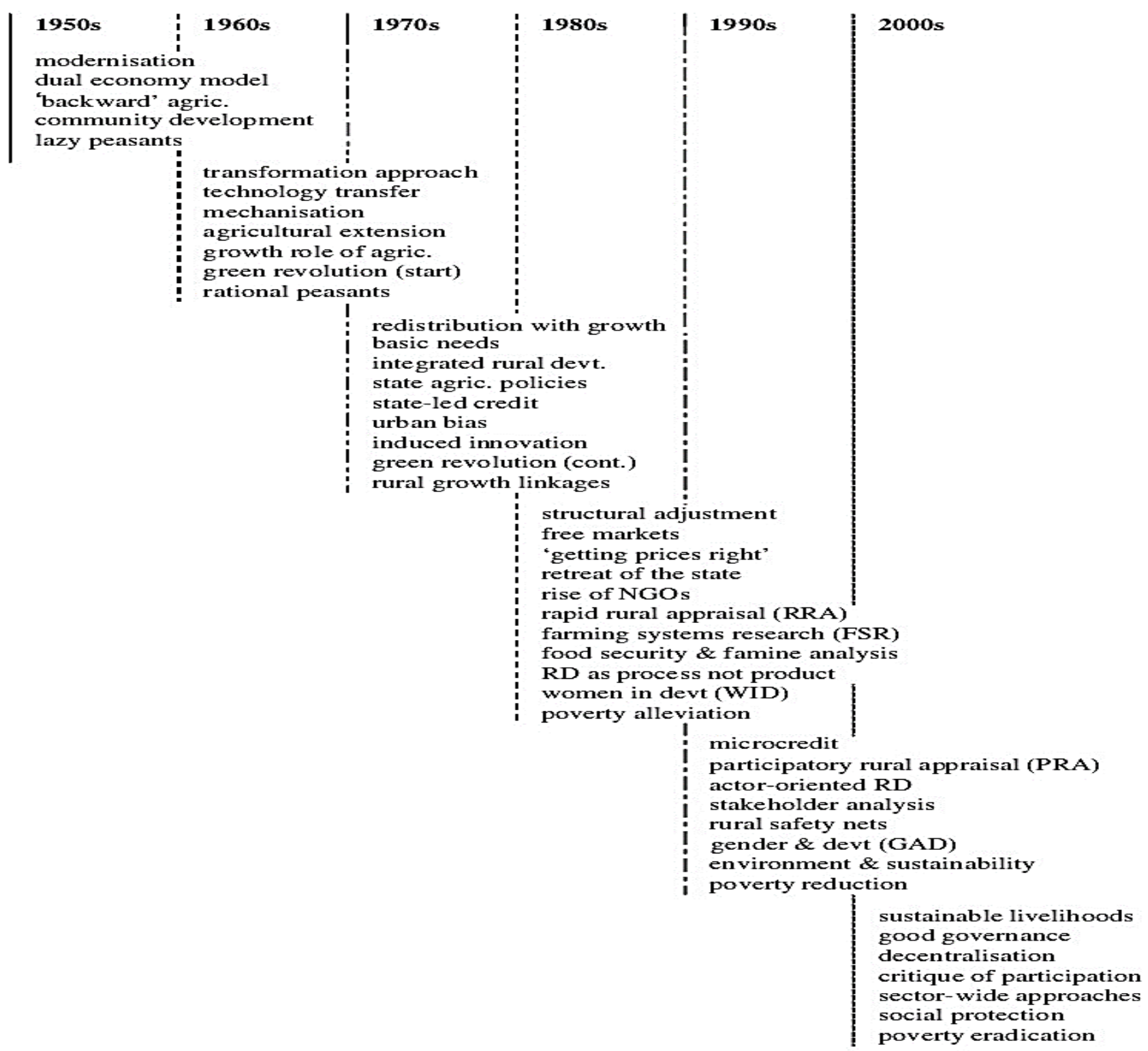

Figure 1. Rural development time-line in the global world (Ellis and Biggs, 2001)

In developing countries where a majority of the rural people used to live, the primary concern is on agricultural production through sustainable farming (Turunen et al., 2010). In addition to farming activities, non-farm economic activities in rural areas also play a significant role in rural development (Neglo et al., 2021; Rantšo, 2016). With special reference to South Asian region, rural poverty situation is severe. In such regions agricultural development initiatives are essential for the overall rural development process (Islam, 2007; Nadeem and Mushtaq, 2012). Agricultural extension services in these regions serve as an essential tool for economic as well as general rural development (Akinola et al., 2011; Dragić and Živković, 2009). It enhances agricultural production through multiple rural and agricultural development activities (Ifeanyi-Obi et al., 2012). Different rural development policies, programmes and initiatives were in progress in different regions of the world during different regimes as described by Ellis and Biggs (2001)s. These initiatives are summarized in Figure 1. With this notion, there is a need to critically analyze rural poverty and its major reasons in rural areas of Pakistan, rational and 
concept of rural development and the rural development initiatives being in progress by the public, private and voluntary sector in Pakistan.

\section{METHODOLOGY}

The current research is based upon secondary data and critical reviews. Review of already published articles/ research papers, research reports of different development organizations like FAO, UNDP, IFPRI, etc., were thoroughly reviewed, keeping in mind the study's objectives. This review process was started in January 2021 and end in June 2021. The inclusion and exclusion of research articles and research papers were completely based on the main themes of the research. Content analysis technique was applied for the analysis of qualitative data collected from the literature.

\section{RESULTS AND DISCUSSION Rural Poverty in Pakistan}

Poverty is a multi-dimensional phenomenon and covers both income and non-income-based perspectives. Poverty may be dynamic or statistic, as explained by Ashfaq et al. (2009). Three dimensions of poverty as described by UNDP (2020) are given in Figure 2.

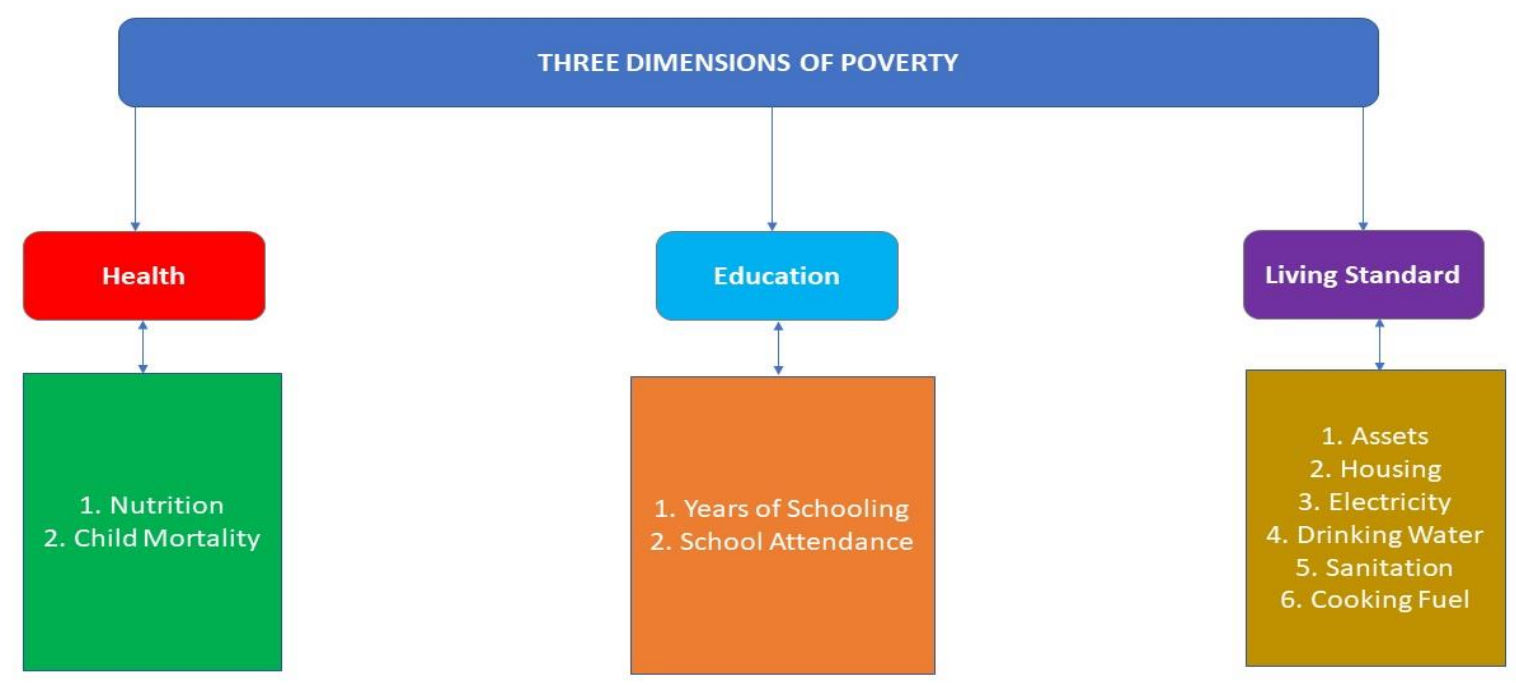

Figure 2. Dimensions of poverty (Source: UNDP, 2020).

Different researchers explain poverty in different ways. According to Janjua and Kamal (2014), it is a deficiency in the overall well-being of an individual. In terms of non-income-based poverty, it is the deprivation of an individual of his/her social, economic and cultural rights. Low level of participation in economic and social activities by an individual is referred to as poor (Bhutto and Bazmi, 2007). On similar lines, Ashfaq et al. (2009) concluded that lack of involvement in social activities by an individual (socially excluded) or powerlessness is the non-income dimension of poverty. This has been by a number of research studies that the majority of the poor and deprived masses of society reside in rural areas (Alkire and Foster, 2011; Hashmi, 2011; Shrestha and Upreti, 2011). There is close interlink and association between rurality and poverty (Luqman et al., 2018). The existence of a high rate of poverty in rural areas is due to the fact that there exists a close interlink between rural poverty and agricultural growth (Hafeez et al., 2011; McMichael, 2009; Weber et al., 2005). In this situation, there is dire need to sustainable rural development policies for maximum poverty reduction from the rural masses.

Like other developing countries of the world, poverty in Pakistan is also referred to as a rural phenomenon. Research studies showed that people living in rural areas are commonly deprived of basic necessities of life. Minimum employment and income generation activities are found in rural areas due to which people of rural areas are experiencing high poverty rates than others (Chaudhry et al., 2012, 2006; Chaudhry and Rahman, 2009; Hashmi, 2011; Ikram et al., 2010). The poverty situation in rural areas of Pakistan is very clear from Figure 3, showing the multidimensional poverty index at the provincial and national levels explained by UNDP (2021). 


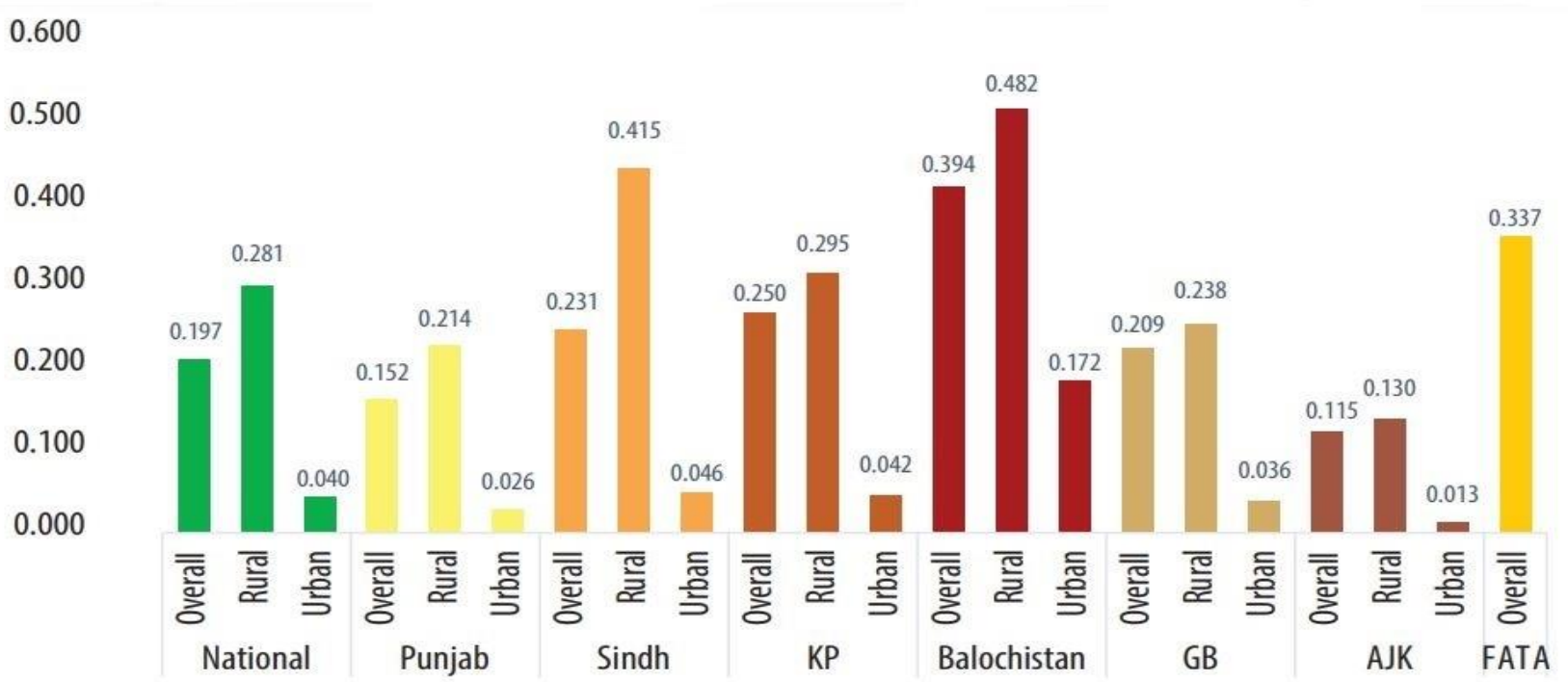

Figure 3. Multidimensional poverty index at the national and provincial level (Source: UNDP, 2020).

The reasons behind the high rate of poverty in rural areas with reference to Pakistan are multiple. Out of these, the small size of land holding possessed by a majority of the farmers is very much common (Ghafoor et al., 2010). Lack of technical knowledge and training, as well as availability of minimum infrastructure facilities, are also contributing towards rural poverty (Thapa, 2009). Low literacy rate, limited access to employment and other income generation activities to rural people are boosting the poverty level (Shahbaz et al., 2008). Unequal distribution of resources among different rural masses is also one of the major causes towards poverty in rural areas (IFAD, 2011).

\section{Rational and Concept of Rural Development}

The rational and real concept of rural development is well explained by a number of development practitioners in the world (Brennan, 2009). It is a complex, multidimensional and multi-sectoral phenomenon/process (García et al., 2008). It involves a number of concepts like local community empowerment, improvement in educational and health facilities, equality and participation in all the development activities by all sections of the society (Al-Jayyousi, 2009). According to Ekong (2010), rural development covers multiple needs of the rural community. Nlerum (2013) concluded that rural development is a continuous process of change in the entire behaviour and socio-economic status of rural community. According to Wandschneider and Davis (2003) rural development process is not limited to agricultural activities. It is a balanced combination of farming as well as non-farming economic activities (World Bank (2002). It is a holistic approach covering multiple sectors of the rural economy (Ward et al., 2005). On the similar lines Mashreque and Nasrullah
(2005) concluded that social, economic and physical development of rural community. In developing regions like Pakistan, the element of rural development is very much important and gain maximum importance due to the fact of high poverty rate in rural localities (Adisa, 2012). The overall economic development in these countries is highly depend upon on-farm as well as offfarm economic and development activities (Ngeh, 2013). Research studies proved that rural development activities play a significant role in the well-being of local rural community as well as also enhance the agricultural production that ultimately contributes towards national economic growth and development (Francis and David, 2012).

\section{Rural Development Initiatives in Pakistan}

From the archives, it is clear that accounting and providing plans for social welfare of the rural poor in Pakistan is long enough, and it continued since freedom involving multiple approaches and strategies executed by the state-led departments, but majority of them had little success (World Bank, 2007). In the global world, the impact of agriculture development on rural livelihood is obvious and it is among the major economic activities executed in the rural areas (Haq, 2003). The most important challenge in developing countries is to increase agricultural production on sustained and regular basis to eradicate rural poverty especially in rural areas (Ade Freeman et al., 2004) as big majority of poor households live in rural areas of the world (Islam, 2007). This situation exacerbates the poverty ratio in the adjacent areas, and individuals get involved in nonfruitful activities. It further impairs the national progress when a large number of individuals could not afford the services as well as goods to meet the basic necessities. Graph under explain the per capita poverty rate of Pakistan 
of last 15 years and gives an estimation of next two years

as well (Figure 4).

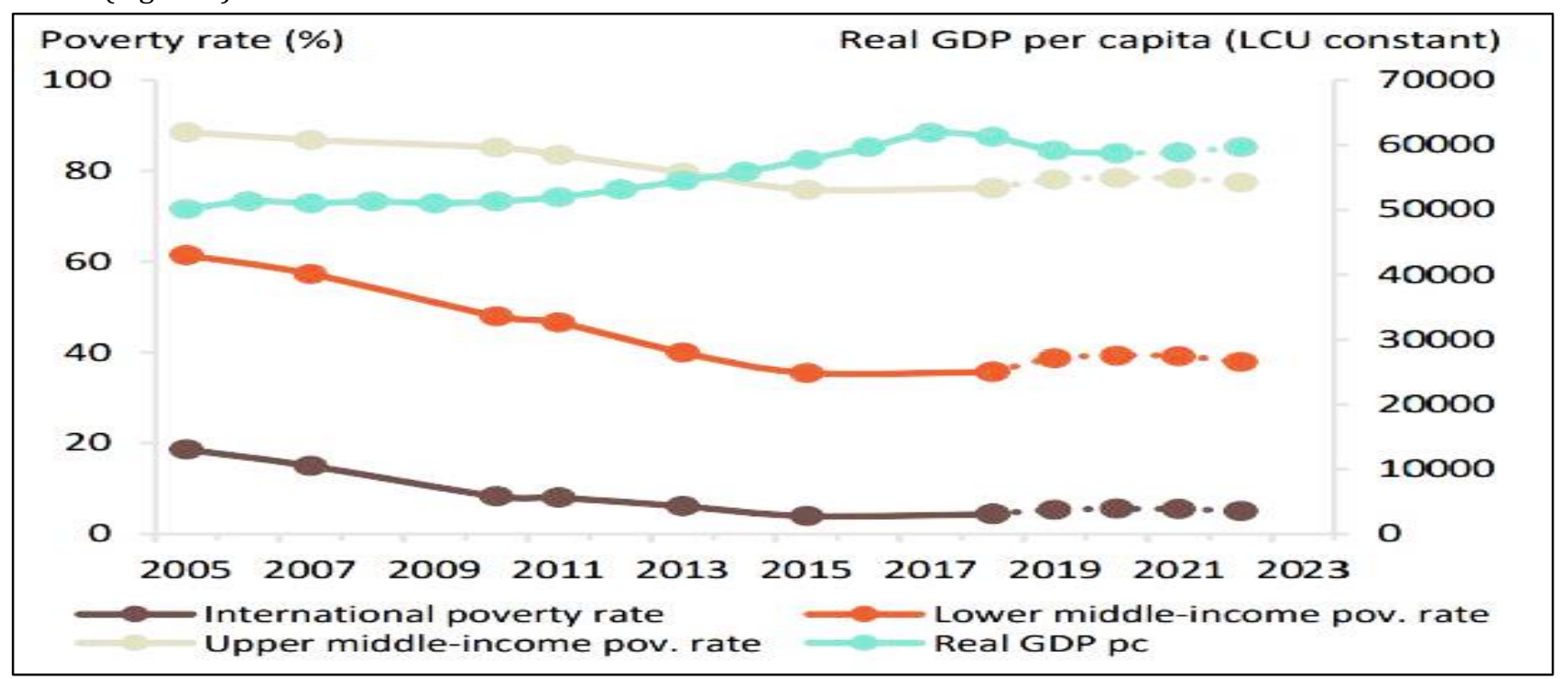

Figure 4. Actual and projected poverty rates and real GDP per capita (Source: World Bank, 2021)

Like remaining developing countries in Pakistan, agriculture is the single largest sector that contributes a lot to the national economy, and due to this reason, it serves as the backbone of national revenue (Government of Pakistan, 2021). Low income is not the only issue of rural people but they also lack basic needs such as education, clean drinking water, health, and proper sanitation, which excavate their capabilities, limits their chances to secure employment which results in social exclusion at the end (Hussain et al., 2003). To improve rural life through increased production and growth, the Government has tested various models and approaches to rural development. The first one among these rural development programmes was initiated in 1952. The name of the program initiated was Village Agricultural and Industrial Development Programme (Village-AID) (Tajima, 1994). The main objectives of this programme were to enhance the earning of rural people by adopting improved farming techniques and involving in cottage industries. This programme was designed to inculcate a sense of selfhelp among rural people so that they could solve their problems themselves. Coordination of developmental activities carried by the departments and agencies relevant to rural development and agriculture specifically was the focus of this program. They were, moreover, imparting welfare orientation gradually into the entire administrative structure of the government. In the start, this program accomplished considerable success but later became a target of political change in the country and departmental jealousies at a local level (Davidson and Ahmad, 2017).
The termination of the Village-AID program in 1961, Basic Democracies System (BDS) adapted the task of rural development in Pakistan. The BD system also faced the same fate as the predecessor program and could not achieve the desired results because the bureaucracy enjoyed the dominant positions in decision-making, planning and implementation of local rural development plans. Only the big landholders could take advantage of the production facilities like provision of inputs (fertilizer, seed etc.) at a subsidized rate, interestfree agricultural loans so that the rural economy can be improved on a sustained basis (Khan and Khan, 2001). In the first half decade of the 1970s, the "new" government abolished the BDS and brought into effect a new programme with the name of 'Integrated Rural Development Program' (IRDP). This programme envisaged to provide concerted support in multiple sectors, i.e., education, housing, health, water, and agricultural services, to make the rural community a productive unit of development at a local level with multi-sectoral facets. The results of this programme indicate that it helped in installing basic institutions and acquired some material gains, but its impact on the poor was minimal (Davidson et al., 2001). The major reason for its failure was the poor performance of agriculture sector and low level of institutional capacity. Rural works programme under BDS was running together with IRDP but was known with the name of People's Works Programme during 1972-80 (Chaudhary, 2002). This programme also terminated due to departmental jealousy and its top-down nature of implementation. 
In the period of 1985-88 the Prime Minister pinpointed five areas to promote the wellbeing and opulence of rural masses. The programme succeeded to a greater extent but its fate was also limited due to change in political power (Luqman et al., 2007). After this short span program in the year 1991, Tameer-e-Watan programme was launched in the country; elected members of the National and Provincial Assembly and senators also participated in this programme. Physical infrastructure development was boosted under the umbrella of this program but holistically, its contribution was not satisfactory. Sudden change in political power and corruption were the two main reasons for its lack of performance (Khan and Khan, 2001). Social Action Programme (SAP) with the support of international donors started in 1993 (Azizi, 1999). Due to change in the political scenario in the country, the programme was abolished and, again a new programme known as "Khushal Pakistan Programme" (KPP) was launched by the state to improve the livening conditions of rural people, in two phases with the objective to provide basic services for the people living at the grassroots level. The main accent of this programme was given on infrastructure development. However, once again the change in political regime in the country, the Devolution of Power Plan was brought into effect (in 2001) to edify the economic status of people living in rural areas through pooling their sources and resources at the ground level (Lodhi et al., 2006).

From the above said it is clear that the state efforts to provide adequate basic social and welfare services to the rural masses and the overall performance of stateled rural development programmes have been quite disappointing in terms of their ability to reach the poor and to produce a significant impact on the living standard of the rural population. It is a general fact that rural development in Pakistan is characterized by politically motivated short-term and inconsistent projects without any kind of feedback (Rehman, 2005). All the initiatives taken for rural development by the different Governments of Pakistan were abolished one after the other. Limitations and drawbacks at various levels caused the termination of each one of them. Lack of political stability in the country and situation of rivalry instead of coordination among the different government institutes are some of the major barriers for the failure of different strategies of rural development (Sadaf et al., 2005). Before 2008 it was a dream for Pakistan that there would ever happen the smooth transformation of political power. This scenario has left consequential impact on the sector which already faces natural disasters of multiple categories. Figure 5 gives an overview of the political stability situation from 2000s.

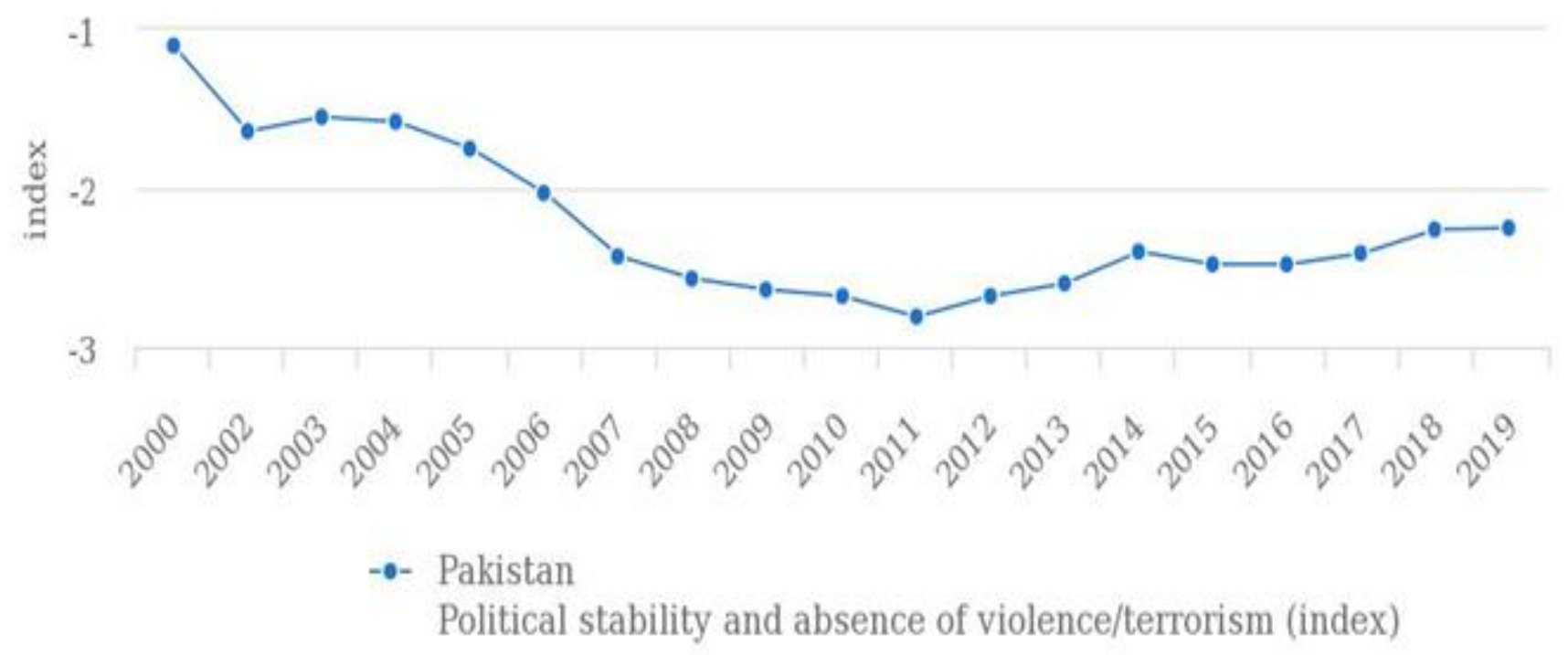

Figure 5. Political stability graph (Source: FAO, 2021).

Most of the time, it is perceived that majority of the community that state institutions are ravening and ineffective in providing basic social services such as education, sanitation, health, water and shelter to the common people which results in rising role of civil society organizations (CSOs). These organizations in the form of religious groups, professional associations and other locally rooted organizations flourish to compete and make the state institutions more accountable (UNAIDS, 2001). Besides state institutions, many programmes for 
supporting rural areas are striving at the verge to meliorate the rural livelihoods but in vain and poverty still exists in the country (Majeed et al., 2006).

\section{CONCLUSIONS}

From the above discussion and critical review analysis of different rural development plans and strategies implemented by Government and Non-Government organizations, it is concluded that rural development programmes in Pakistan failed due to many reasons. Political instability, corruption, top-down oriented development schemes and jealousy and rivalry among allied departments are some major causes of the failure of these development plans. In the light of the literature review and shortcomings and problems in the existing rural development strategies, it is recommended that in the planning and implementation procedure of rural development plans, the participation of local people should be encouraged. Moreover, western and foreignfunded NGOS should be involved in rural areas' development process, including religious groups who engaged in the social welfare work in the area. Conclusively, the rural development time-line in Pakistan is well summarized in Figure 6.

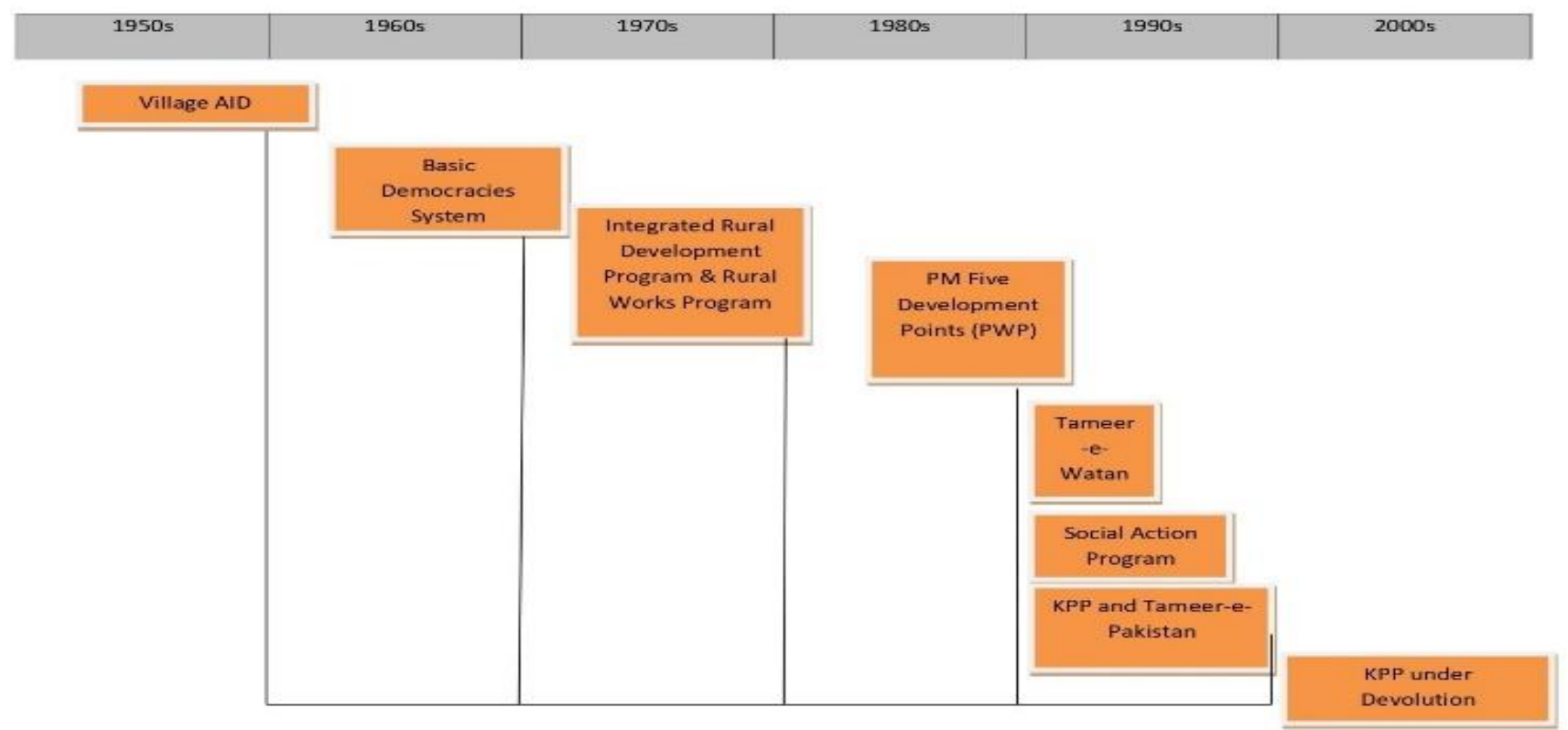

Figure 6. Rural development time-line in Pakistan.

\section{REFERENCES}

Ade Freeman, H., Ellis, F., Allison, E., 2004. Livelihoods and rural poverty reduction in Kenya. Dev. policy Rev. 22, 147-171.

Adisa, R.S., 2012. Rural development in the 21st century as a global necessity. Rural Dev. issues Pract. InTech Publ. Rijeka, Croatia.

Akinola, M.O., Issa, F.O., Sanni, S.A., 2011. Agricultural extension systems in West Africa: Adoptable strategies for Nigeria's agricultural extension reform agenda. J. Agric. Ext. 15, 1-7.

Al-Jayyousi, O., 2009. Islamic values and rural sustainable development. Rural 21 J. 43, 39-41.

Alkire, S., Foster, J., 2011. Counting and multidimensional poverty measurement. J. Public Econ. 95, 476-487.

Ashfaq, M., Griffith, G., Hussain, I., 2009. Economics of water resources in Pakistan: Water and Poverty. Pak. TM Printers, Pakistan.

Azizi, S.L., 1999. An Analysis of the social action program and education of women in Pakistan. Virginia Polytechnic Institute and State University.
Bhutto, A.W., Bazmi, A.A., 2007. Sustainable agriculture and eradication of rural poverty in Pakistan, in: Natural Resources Forum. Wiley Online Library, pp. 253-262.

Brennan, M.A., 2009. IFAS Community development: The continuing importance of rural development. Gainesv. Univ. Florida IFAS Extension, FCS0242.

Chaudhary, K.M., 2002. Community infrastructure services programme (CISP): Human resource development manual. Department of Local Government and Rural Development, Government of Azad Jammun and Kashmir, Muzaffarabad, Pakistan.

Chaudhry, I.S., Faridi, M.Z., Hanif, I., 2012. The whimsical trends of rural poverty in Pakistan: some diversifications. Int. Res. J. Financ. Econ. 83, 78-89.

Chaudhry, I.S., Malik, S., Ashraf, M., 2006. Rural poverty in Pakistan: some related concepts, issues and empirical analysis. Pak. Econ. Soc. Rev. 259-276.

Chaudhry, I.S., Rahman, S., 2009. The impact of gender inequality in education on rural poverty in Pakistan: an empirical analysis. Eur. J. Econ. Financ. Adm. Sci. 15, 174-188. 
Davidson P.A., Ahmad, M., T. Ali, T., 2001. Dilemmas of agricultural extension in Pakistan: Food and thought, agricultural research and extension Network. On-line Research Paper No.116.

Davidson, A.P., Ahmad, M., 2017. Privatization and the crisis of agricultural extension: The case of Pakistan. Routledge.

Dragić, L., Živković, S.J., 2009. The role of knowledge, innovation and human capital in multifunctional agriculture and territorial rural development. Agric. Ext. Serv. Funct. Rural Dev. 2-3.

Ekong, E.E., 2010. Rural sociology. Dove Educ. Publ. Uyo Niger. 1-425.

Ellis, F., Biggs, S., 2001. Evolving themes in rural development 1950s-2000s. Dev. policy Rev. 19, 437448.

FAO, 2021. FAOSTAT-Pakistan. Retrieved from: http://www.fao.org/faostat/en/\#country/165

Francis, N., David, A.K., 2012. The challenges of agriculture and rural development in Africa: the case of Nigeria. International Journal of Academic Research in Progressive Education and Development 1(3), 45-61.

García, L.B., Dávila, J.P.M., López, F.G., 2008. Sustainable rural development: that distinguished stranger (a review). Rev. Científica 18, 43-50.

Gautam, Y., Andersen, P., 2016. Rural livelihood diversification and household well-being: Insights from Humla, Nepal. J. Rural Stud. 44, 239-249.

Ghafoor, A., Hussain, M., Naseer, K., Ishaque, M., Baloch, M.H., 2010. Factors affecting income and saving of small farming households in sargodha district of the Punjab, Pakistan. Pakistan J. Agric. Agric. Eng. Vet. Sci.

Government of Pakistan, 2021. Economic survey of Pakistan, Economic Advisor's Wing, Islamabad, Pakistan.

Hafeez, N., Ashfaq, M., Sarwar, I., Bari, A., 2011. The contribution of crop income in reducing poverty and income inequality among different farm sizes: a comparison of cotton/wheat and barani Punjab. Pak. J. Agri. Sci 48, 155-158.

Haq, 2003. Human development in South Asia 2002. Published by Oxford University Press, Karachi, Pakistan. pp. 24.

Hashmi, M.S., 2011. Land distribution, technological changes and productivity in pakistan's agriculture: some explanations and policy options. Management 1, 51-74.

Hussain, S., Saddiqui, B.N., Mukhtar, Y., Hassan, M.Z.Y., 2003. Impact of loan facilities provided by Punjab Rural Support Program for poverty alleviation in farming communities of Faisalabad. Int. J. Agri. Biol 5, 658-659.
IFAD, 2011. Sector-wide approaches for agriculture and rural development: Policy. International Fund for Agricultural Development (IFAD), Rome, Italy. www.ifad.org.

Ifeanyi-Obi, C.C., Etuk, U.R., Jike-Wai, O., 2012. Climate change, effects and adaptation strategies; implication for agricultural extension system in Nigeria. Greener J. Agric. Sci. 2, 53-60.

Ikram, A., Abdul, S., Sarfraz, A., 2010. A profile of regional contribution of rural poverty in Punjab: some hidden dynamics. Pakistan J. Life Soc. Sci. 8, 35-41.

Islam, N., 2007. Reducing poverty and hunger in Asia: the role of agricultural and rural development. Twenty twenty Focus briefs/International Food Policy Res. Inst. (IFPRI); 15.

Janjua, P.Z., Kamal, U.A., 2014. The role of education and health in poverty alleviation a cross country analysis. J. Econ. Manag. Trade 896-924.

Khan, A.R., Khan, A.N., 2001. An overview of rural development programmes and strategies in Pakistan. J. Rural Dev. Adm. 33, 22-29.

Lodhi, T.E., Luqman, M., Khan, G.A., 2006. Perceived effectiveness of public sector extension under decentralized agricultural extension system in the Punjab, Pakistan. J. Agric. Soc. Sci. 2,195-200.

Luqman, M., Ahmed, K., Ashraf, M., Khan, Z.I., 2007. Effectiveness of decentralized agriculture extension system in Pakistan, in: African Crop Science Conference Proceedings. pp. 1465-1472.

Luqman, M., Ashraf, S., Shahbaz, B., Butt, T.M., Saqib, R., 2021. Rural development through non-state actors in highlands of Pakistan. SAGE Open 11, 21582440211007130.

Luqman, M., Saqib, R., Karim, M., Nawab, K., Rehman, A., Yaseen, M., 2018. Socio-economic impacts of agroforestry on livelihoods of rural households in southern region of the Punjab, Pakistan. Sarhad J. Agric 34, 880-887.

Majeed, H.A., Munir, A., Muhammad, L., 2006. Attitude of farmers towards extension work conducted by the PRSP Field Unit, Muzaffargarh (Pakistan). J. Agric. Soc. Sci. 2, 120-121.

Mashreque, M.S., Nasrullah, A.M., 2005. Rural development in Bangladesh: concepts, dimensions and significance. Pakistan J. Soc. Sci. 3, 210-215.

McMichael, P., 2009. A food regime genealogy. J. Peasant Stud. 36, 139-169.

Munawar, M., Shiwei, X., Wen, Y., Luqman, M., 2021. Resilience to food insecurity among rural households in the Punjab, Pakistan. Sarhad J. Agric. 37, 754-762.

Nadeem, N., Mushtaq, K., 2012. Role of agricultural research and extension in enhancing agricultural 
productivity in Punjab, Pakistan. Pakistan J. Life Soc. Sci. 10, 67-73.

Neglo, K.A.W., Gebrekidan, T., Lyu, K., 2021. The Role of agriculture and non-farm economy in addressing food insecurity in Ethiopia: A Review. Sustainability $13,3874$.

Ngeh, D.B., 2013. Non-governmental organizations (NGOS) and rural development in nigeria. Mediterr. J. Soc. Sci. 4, 107.

Nlerum, F.E., 2013. Review of evaluation models for determining impact of rural development projects. Spanish J. Rural Dev. 4, 1-8.

Rantšo, T.A., 2016. The role of the non-farm sector in rural development in Lesotho. J. Mod. Afr. Stud. 54, 317-338.

Rehman, F., 2005. Rural development in the mountainous areas of Pakistan: Integration of village organizations in the planning process: some observations from Astor Valley, Northern Pakistan. J. Rural Dev. Adm. 36, 37-65.

Sadaf, S., Muhammad, S., Lodhi, T.E., 2005. Need for agricultural extension services for rural women in Tehsil Faisalabad, Pakistan. J. Agric. Soc. Sci. 1, 248-251.

Saqib, R., Luqman, M., Javed, I., Rehman, A., Yaseen, M., Ashraf, S., Majeed, M.Z., 2019. Livelihood strategies of small-scale farmers in Pakistan in the scenario of climate change. Sarhad J. Agric 35, 1298-1308.

Shahbaz, B., Mbeyale, G., Haller, T., 2008. Trees, trust and the state: A comparison of participatory forest management in Pakistan and Tanzania. J. Int. Dev. J. Dev. Stud. Assoc. 20, 641-653.

Shrestha, L., Upreti, B.R., 2011. Reflection on land-based relationship between agrarian tension, armed conflict and human insecurity in Nepal. Land, Agric. Agrar. Transform. 57.

Singh, A.S., 2007. Agriculture and rural development in the Greater Mekong Sub-Region The Important Nexus.

Tajima, S., 1994. Typological analyses of agricultural extension systems. In Agricultural Extension Systems in Asia and the Pacific: Report of an APO Study Meeting, 15th-25th June, 1993, Tokyo, Japan. Asian Productivity Organization, p. 33.
Thapa, N., 2012. Impact of climate change on food security: A case of Dailekh district, Nepal. Participation 14(13), 49-58.

Turunen, J., Snäkin, J., Panula-Ontto, J., Lindfors, H., Kaisti, H., Luukkanen, J., Magistretti, S., Mang, C., 2010. Livelihood Resilience and Food Security in Cambodia-Results from a Household Survey. Helsinki, Finl. Futur. Reserach Cent.

UNAIDS, 2001. The assessment and mitigation of the impact of transport infrastructure and services on the spread of HIV/AIDS. Retrieved from: https://hdl.handle.net/20.500.12870/2977.

UNDP, 2020. Charting pathways out of multidimensional poverty: Achieving the SDGs. United Nations Development Programme and Oxford Poverty and Human Development Initiative. Development Policy Unit, Islamabad, Pakistan.

UNDP, 2021. Multidimensional poverty in Pakistan. United Nations Development Programme for Pakistan. Development Policy Unit, Islamabad, Pakistan.

Wandschneider, T., Davis, J.R., 2003. Best practice and strategies for promoting rural non-farm employment through project interventions (NRI report no. 2756).

Ward, C., Dargought, S., Minasyan, G., Gambarelli, G., 2005. Reneging in agricultural water management: challenges, opportunities and trade-offs. Agric. Rural Dev. (ARD), World Bank, Washingt. DC, USA.

Weber, B., Jensen, L., Miller, K., Mosley, J., Fisher, M., 2005. A critical review of rural poverty literature: Is there truly a rural effect? Int. Reg. Sci. Rev. 28, 381-414.

Welteji, D., 2018. A critical review of rural development policy of Ethiopia: access, utilization and coverage. Agric. Food Secur. 7, 1-6.

World Bank, 2007. Pakistan promoting rural growth and poverty reduction. Report No. 39303-PK. Sustainable and Development Unit, South Asia Region.

World Bank. 2018. Poverty and Equity Database. In: The World Bank [online]. Washington, DC.

World Bank, 2021. Pakistan - Macro Poverty Outlook. Retrieved from: https://bit.ly/3jCfxF8.

Publisher's note: Science Impact Publishers remain neutral with regard to jurisdictional claims in published maps and institutional affiliations.

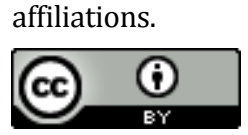

Open Access This article is licensed under a Creative Commons Attribution 4.0 International License, which permits use, sharing, adaptation, distribution and reproduction in any medium or format, as long as you give appropriate credit to the original author(s) and the source, provide a link to the Creative Commons license and indicate if changes were made. The images or other third-party material in this article are included in the article's Creative Commons license, unless indicated otherwise in a credit line to the material. If material is not included in the article's Creative Commons license and your intended use is not permitted by statutory regulation or exceeds the permitted use, you will need to obtain permission directly from the copyright holder. To view a copy of this license, visit https://creativecommons.org/licenses/by/4.0/. 